\title{
PEMBINAAN IBU RUMAH TANGGA MELALUI JUAL BELI SECARA E-COMMERCE DI PERUMAHAN CITRA LAGUNA
}

\author{
Tiurniari Purba \\ Universitas Putera Batam (UPB), Batam, Indonesia \\ email: tiurniari@gmail.com \\ Irene Svinarky \\ Universitas Putera Batam (UPB), Batam, Indonesia \\ email: Irene@gmail.com
}

\begin{abstract}
Community Service (PKM) aims to foster housewives in Citra Laguna Housing, Batam. More than 50 percent of the housewives in this housing simply carry out the profession as a housewife without any other activities. Meanwhile, complaints about the inadequacy of household needs are very high. They want extra money to make ends meet. Through this PKM, the implementation method forms direct training and practice on making homemade ice cream products and selling them online or e-commerce. Implementation is carried out twice per meeting. First, fostering participants and practice on how to make ice cream, which was represented by 15 participants. Second, teach and practice buying and selling online through internet media such as through Facebook, Instagram, and others (e-commerce which is familiar among housewives). The results during the two meetings are as follows: 1. Housewives mastered how to make ice cream products with satisfactory results. 2. Housewives know how to download images of products they want to sell in common marketing languages.
\end{abstract}

Keywords_coaching, housewives, buying and selling, e-commerce

\section{PENDAHULUAN}

Situasi sulit sekarang yaitu akibat dampak pandemic Covid-19, membuat situasi perekonomian menjadi terganggu, termasuk kondisi keuangan rumahtangga. Adanya waktu luang ibu rumah tangga, bisa dimanfaatkan untuk menghasilkan sesuatu yang bernilai jual. Ibu-ibu di perumahan Citra Laguna, lebih dari 50 persen murni menjalankan peran tanpa ada pekerjaan sampingan yang bisa menghasilkan uang. Produktivitas seorang ibu rumah tangga di perumahan tersebut sangat jarang yang digunakan untuk melakukan bisnis, baik itu bisnis secara off line maupun on line atau sering disebut dengan istilah $e$ commerce. Dengan bantuan teknonogi, ecommerce menunjang penjualan dan pembelian (Yulistia, 2017).

Apabila ada sesuatu yang bisa diciptakan oleh ibu rumah tangga untuk dijual maka hal tersebut dapat membantu menambah penghasilan keluarga selain pendapatan suami. Tidak semua pendapatan yang dihasilkan oleh suami dapat mencukupi kebutuhan sehari-hari. Tujuan Pengusul mengajukan pengabdian ini untuk mengupayakan ibu-ibu rumah tangga menjadi kreatif dan 
mampu mencari uang tambahan untuk menunjang perekonomian keluarga apalagi adanya dukungan gadget yang selalu ada di tangan (Pradana, 2015). Nainggolan et al (2021) misalnya melakukan pengabdian dengan memberikan pelatihan tokoh online dimasa pademi merupakan upaya memberikan penghasilan tambahan bagi ibu rumah tangga. Oleh sebab itu Pengabdi melalui Program PKM ini memerlukan wadah dimana selama 2 kali pertemuan, tim pengabdi dapat membina para ibu-ibu agar secara ekonomi dapat menghasilkan sesuatu yang bernilai uang. Sasaran lokasi dari pengabdian ini adalah komplek perumahan Citra Laguna, Tembesi, dengan 15 peserta.

Metode pelaksanaan pengabdian ini dilakukan dengan praktek langsung bersama ibu ibu rumah tangga, yaitu praktek membuat dan mengahasilkan produk ice cream di pertemuan pertama (Istiqomah et al., 2017). Selanjutnya pada pertemuan kedua akan diadakan penyuluhan dan praktek jual beli secara online melalui media internet seperti facebook, instagram, dan lain lain (ecommerce yang familiar dikalangan ibu-ibu rumah tangga) (Kasmi \& Candra, 2017). Sebenarnya pembuatan es krim itu mudah dan praktis dan tidak perlu mengeluarkan biaya yang begitu banyak karena harga bahan-bahannya juga sangat sederhana. Berikut tiga resep kepada kamu pecinta eskrim yang ingin mencoba membuat eskrim sendiri.

Keterkaitan antara hukum dengan ekonomi dalam penjualan ini adalah bagaimana cara pemasaran es krim ini secara e-commerce dan perjanjian jual belinya. Perjanjian yang diatur di dalam hukum tidak hanya dilakukan antara penjual dan pembeli saja tetapi juga harus diketahui aspek dan syarat perjanjian yang ada di dalamnya, sehingga perjanjian tersebut yang menimbulkan akibat hukum tidak merugikan konsumen. Tujuan pemasaran dari produk ini adalah untuk dapat mengambangkan usaha ibu-ibu rumah tangga agar mendapatkan penghasilan tambahan selain penghasilan yang diberikan oleh suami. Berdasarkan pembuatan es krim yang akan diberikan oleh Tim pengabdi agar kreativitas ibu-ibu dapat tergali dan juga incomenya dapat bertambah. Penjualan es krim ini nantinya dapat juga di jual secara online, tetapi online yang dimaksud di sini adalah pemesanannya saja namun dapat diantarkan.

Transaksi yang dilakukan secara online yang direncanakan oleh Tim pengabdi hanya dilakukan melalui pesanan WA, Facebook, instagram dan juga hanya melayani pemesanan di wilayah Kota Batam saja. Sifat yang terkandung di dalam es yang bersifat cair, maka tidak memungkinkan es di kirim ke luar kota. Bagi-ibu-ibu yang mau belajar membuatnya di saat pengabdian ini juga tidak memiliki dana besar untuk mendirikan usaha terlebih dahulu sehingga melayani penjualan skala besar. transaksi jual beli secara online atau E-Commerce secara hukum adalah sah, namun di dalam konteks hukum itu sendiri pemenuhan persyaratan dan barang yang diperjualbelikan harus jelas semua, sehingga antara penjual dan pembeli sama-sama merasa diuntungkan karena telah terlaksana hak dan kewajiban.

Kelebihan dari cara jual secara e-commerce, penjual dan pembeli tidak perlu bertatap muka (face to face) untuk melakukan transaksi, melainkan hanya perlu memiliki koneksi internet yang akan mempertemukan mereka di dunia virtual. Oleh sebab itu sifat es yang mudah mencair, membuat Tim pengabdi harus mengarahkan ibu-ibu rumah tangga hanya membuka pelayanan via online disekitaran Kota Batam saja. Kesukaan orang-orang terhadap eskrim tidak memandang usia mereka, karena es krim disenangi baik anak kecil, dewasa, dan orang tua. Pembelian bahan-bahannya mudah sekali untuk dijangkau, baik itu tempat, harga maupun rasanya juga enak. Rasa es yang manis, membuat es menjadi produk yang memiliki nilai jual, dan variannya sangat cepat dikenal ke 
masyarakat. Eksistensi E-Commerce ini penting untuk dikaji aspek legalitasnya, agar tidak menjadi sengketa hukum yang dapat merugikan berbagai pihak secara komersial. E-commerce belakangan ini digemari oleh kalangan produsen baik besar maupun kecil serta penjual eceran umumnya. Hal ini karena promosi melalui media online lebih mudah menjangkau konsumen dalam hal memperkenalkan atau menjual produknya. E-commerce mempermudah antara konsumen dan produsen dalam melakukan transaksi (Helmalia \& Afrinawati, 2018).

Sesuai dengan ciri cirinya maka usaha e-commerce dibagi menjadi dua bagian yaitu:

1. Disebut dengan Bussines two Bussines (B2B). Adapun ciri cirinya adalah:

a. Trading partners bisa dikatakan sudah salih memahami karena sudah terjadi hubungan bisnis yang berlangsung lama.

b. Karena hubungan kedua belah pihak sudah berlangsung lama maka pertukaran data dilakukan secara berulang-ulang dan berkala denga format data yang telah disepakati bersama.

c. Ada hubungan bisnis yang berlangsung lama membuat salah satu pelaku tidak harus menunggu rekan mereka lainnya untuk mengirimkan data.

d. Model yang umum digunakan adalah peer to peer, dimana procesing intellegence dapat didistribusikan di kedua pelaku bisnis.

2. Bussines two Constemer (B2C). Karakteristiknya:

a. Terbuka untuk umum, dimana informasi disebarkan secara umum pula.

b. Service yang digunakan oleh banyak orang.

c. Sering dilakukan sistem pendekatan clien-server.

Adapun kajian aspek legalitas sebagaimana diuraikan berikut ini: keabsahan kontrak elektronik e-commerce lahir berdasarkan kontrak jual beli yang terjadi secara elektronik antara penjual dan pembeli. E-commerce telah berlaku efektif di banyak negara, seperti di Cina e-commerce membantu meningkatkan perekonomian di sana (Parahyangan, Ekonomi, Studi, \& Ekonomi, 2013: 3). Selain memberikan dampak positif terhadap perkembangan usaha, ecommerce juga tidak selamanya menguntungkan. Dunia internet yang berkembang pesat dianggap berkontribusi terhadap biaya investasi yang relatif rendah dan mampu mengalirkan modal yang besar, dijadikan sebagai media promosi yang besar-besaran. Promosi besar-besaran dengan harapan banyak mendatangkan mengunjung ternyata tidak selamanya menguntungkan (Maryama, 2019: 75). Dari dulu sampai pada saat ini masih terjadi kekosongan hukum di Indonesia, sebab belum mengakomodir tentang syarat-syarat sahnya suatu kontrak elektronik secara khusus. Namun, prinsip dasar keberlakuan suatu kontrak di Indonesia mengacu pada Pasal 1320 KUHPerdata, sehingga dapat pula diterapkan pada kontrak elektronik. Banyak yang masih binggung keterkaitan antara hukum dengan ekonomi dalam pembuatan es krim ini. Namun dalam transaksi yang dilakukan oleh produsen dan konsumen nantinya ketika ibu-ibu telah mampu selain membuat dan juga memasarkan eskrim nantinya, juga harus mengetahui mengenai perjanjian. Adapun syarat sahnya perjanjian menurut Pasal 1320 KUHPerdata adalah:

1) Kedua belah pihak yaitu yang malakukan bisnis sepakat mereka yang mengikatkan dirinya. Keberadaan suatu unsur kesepakatan dalam ECommerce diukur melalui pembeli yang mengakses dan menyetujui penawaran melalui internet. Hal ini dapat diterjemahkan sebagai 
penerimaan untuk menyepakati sebuah hubungan hukum. E-Commerce ini secara tertuang dalam kontrak baku dengan prinsip take it or leave it, sebab seluruh penawaran beserta persyaratan pembelian suatu produk sudah tercantum dan pembeli dapat menyetujuinya atau tidak. Persetujuan yang diberikan oleh pembeli ini menjadi dasar dari kesamaan kehendak para pihak, sehingga kesepakatan dalam kontrak elektronik lahir.

2) Harus memiliki keterampilan dalam hal membuat kesepakatan agar tidak saling merugikan. Cakap menurut hukum adalah orang yang telah dewasa menurut hukum, yaitu seseorang yang telah berumur 21 tahun dan telah kawin, serta tidak di bawah pengampuan. Unsur kecapakan dalam $E$ Commerce sulit untuk diukur, sebab setiap orang (tanpa dibatasi dengan umur tertentu) dapat mejalankan transaksi elektronik sesuai dengan Pasal 2 Undang-Undang Nomor 11 Tahun 2008 tentang Informasi dan Transksi Elektronik ("UU ITE"). Berdasarkan ketentuan ini, anak-anak yang masih di bawah umur dapat melakukan E-Commerce dan tidak memenuhi syarat subjektif dalam Pasal 1320 KUHPerdata. Oleh karena itu, kontrak ini dapat dibatalkan melalui seseorang yang mengajukan pembatalan di pengadilan.

3) Ada sesua entitas tertentu. Suatu hal tertentu adalah barang-barang yan dapat diperdagangkan dan dapat ditentukan jenisnya. Produk yang ditawarkan secara online tertuang dalam bentuk gambar atau foto yang disertai dengan spesifikasi produk tersebut. Namun, tidak ada jaminan bahwa produk tersebut pasti dikirimkan kepada pembeli sekalipun telah membayar melalui sistem pengiriman uang atau transfer melalui bank.

4) Suatu sebab yang halal. Maksud dari suatu sebab yang halal adalah tidak bertentangan dengan undang-undang, kesusilaan, dan kepentingan umum. Dalam E-Commerce harus dipastikan bahwa transaksi jual beli dilakukan dengan prinsip itikad baik oleh penjual dan pembeli. Jika syarat ini tidak terpenuhi, maka kontrak elektronik batal demi hukum.

Berdasarkan pemaparan di atas, E-Commerce telah sah menurut hukum sepanjang memenuhi Pasal 1320 KUHPerdata. Syarat pertama dan kedua disebut dengan syarat subjektif, sebab melekat kepada pihak-pihak yang terlibat dalam E-Commerce. Sedangkan, syarat ketiga dan keempat merupakan syarat objektif, karena melekat pada objek dalam E-commerce. Apabila syarat pertama dan/atau syarat kedua tidak dipenuhi, maka kontrak elektronik dapat dibatalkan oleh pihak yang berkepentingan dalam jangka waktu selama 5 (lima) tahun sesuai dengan Pasal 1454 KUHPerdata. Dalam hal syarat ketiga dan/atau syarat keempat tidak dipenuhi, maka kontrak elektronik batal demi hukum atau dianggap tidak pernah ada dan tidak ada dasar untuk menuntut.

Berdasarkan analisis situasi yang telah paparkan di atas, maka rumusan masalah yang diangkat di Proposal Pembinaan Pengabdian Kepada Masyarakat ini, adalah:

1. Bagaimanakah upaya membina masyarakat (ibu-ibu rumah tangga) untuk meningkatkan perekonomiannya agar dapat membantu keluarga?

2. Bagaimanakah perjanjian jual beli es krim yang penjualannya dilakukan secara e-commerce? 


\section{METODE}

Pengabdian dilaksaakan kurang lebih dua minggu di masyarakat, dilihat dari waktu yang telah ditentukan oleh Lembaga Penelitian dan Pengabdian Kepada Masyarakat, setiap pengusulmemiliki waktu selama dua jam /minggu untuk memberikan Pembinaan. Tempat yang akan dituju dalam pelaksanaan pengabdian kepada masyarakat yaitu: Komplek Perumahan Cipta Laguna Batam. Adapun metode pelaksanaan dari pengusulan penagabdian kepada masyarakat ini adalah:

Tabel 1. Metode Pelaksanaan

\begin{tabular}{|c|c|c|c|}
\hline No & Waktu & Metode Pelaksanaan & Pemateri \\
\hline 1 & 17 Agustus 2019 & 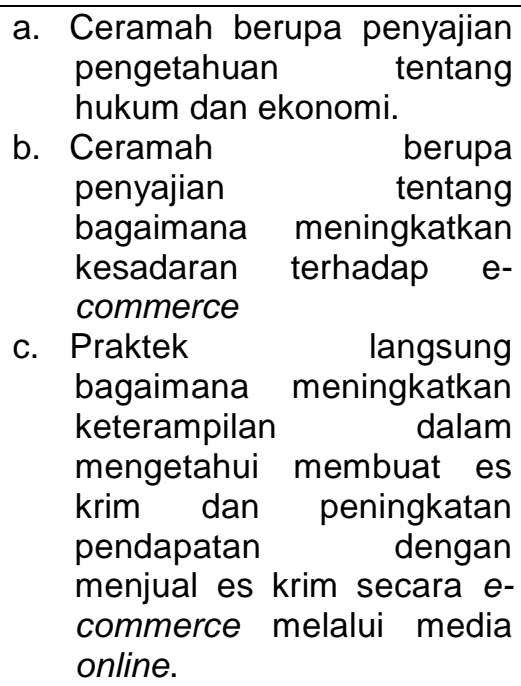 & $\begin{array}{l}\text { Ketua PKM (Irene) } \\
\text { Irene dan Tiurniari } \\
\text { Purba } \\
\text { Irene dan Tiurniari } \\
\text { Purba }\end{array}$ \\
\hline 2. & 18 Agustus 2019 & $\begin{array}{l}\text { a. Mempelajari akibat hukum } \\
\text { yang akan timbul } \\
\text { dikarenakan objek yang } \\
\text { dijual adalah benda yang } \\
\text { cepat cair. } \\
\text { b. Ceramah dan praktek } \\
\text { dengan metode membina } \\
\text { ibu ibu rumah tangga cara } \\
\text { pemasaran ecommerce. }\end{array}$ & $\begin{array}{l}\text { Ketua PKM (Irene) } \\
\text { Anggota PKM } \\
\text { (Tiurniari Purba) }\end{array}$ \\
\hline
\end{tabular}

Untuk menunjang kegiatan dari pengabdian ini adapun peralatan yang harus dipersiapkan untuk kelancaran kegiatan pengabdian ini adalah: Komputer/Laptop, buku yang terkait dengan undang-undang tipikor, akses untuk Mendonwload, peralatan tulis peserta berupa pena, pensil, dan buku, konsumsi selama kegiatan dilaksanakan dan panduk pelaksanaan kegiatan.

\section{PEMBAHASAN}

Suksesnya kegiatan pembinaan yang diberikan kepada ibu-ibu di Perumahan Citra Laguna, Tembesi-Batam, telah menjadi kebanggan tersendiri bagi tim PKM. Beberapa hal yang dilaksanakan oleh tim dosen untuk menyukseskan kegiatan pelatihan dengan praktek langsung secara garis besar dapat dijelaskan sebagai berikut:

1) Survey ke lokasi pengabdian dilaksanakan. 
2) Mengumpulkan dana untuk acara pengabdian seperti biaya mencetak spanduk dan konsumsi.

3) Mencetak spanduk.

4) Belanja untuk konsumsi selama acara pengabdian.
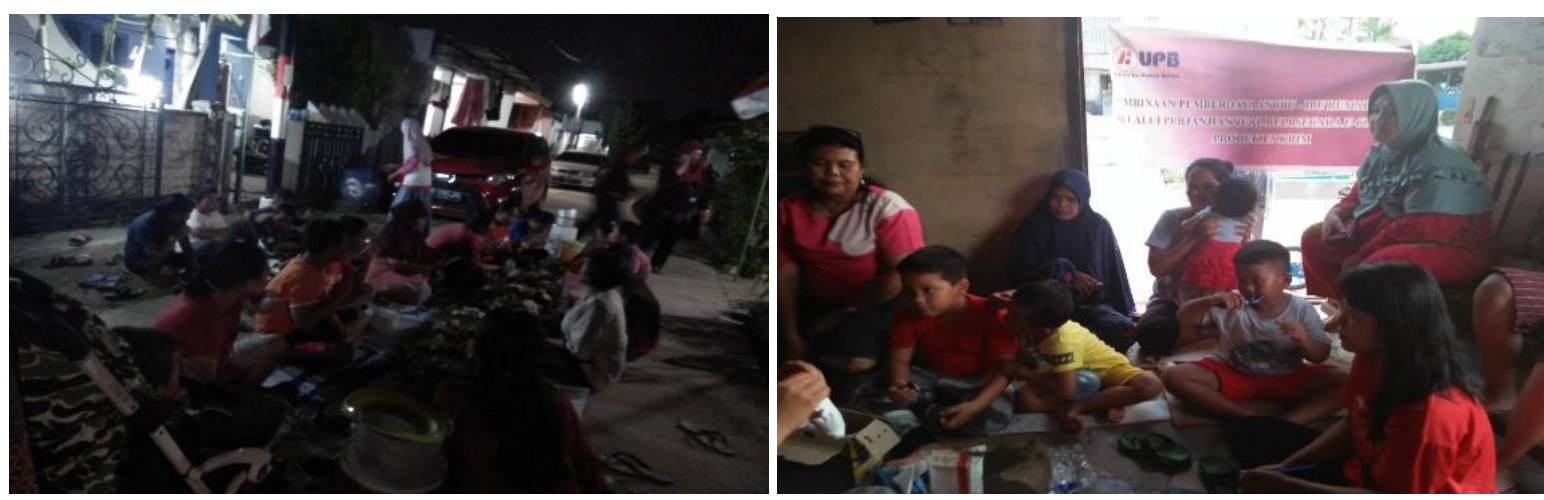

Gambar 1. Pembinaan Ecommerce dan praktek pembuatan es krim

Kegiatan pengabdian yang dilaksanakan di Perumahan Citra Laguna, memberikan respon positif dan dapat diterima dengan baik oleh pihak ibu-ibu di Perumahan Citra Laguna, khususnya ibu-ibu peserta. Antusiasme yang tinggi selama mengikuti kegiatan pembinaan yang pengabdi lakukan.

Dalam kegiatan ini, sebelum memberikan materi dan pemahaman mengenai cara membuat es krim dan cara menjalankan ecommerce, terlebih dahulu tim pengabdi melakukan tanya jawab kepada peserta. Dengan cara ini, maka akan dapat dengan mudah memberikan pemahaman kepada peserta. Penjelasan juga difokuskan pada materi yang kurang dipahami. Sebagai hasil dari selama pelaksanaan PKM Pada ibu-ibu di Perumahan Citra Laguna, Tembesi-Batam, respon para peserta sangat positif dengan tidak mau ketinggalan praktek dan harus praktek dengan tangan sendiri, baik ketika membuat pengolahan es krim maupun ketika mengelola cara pemasaran secara ecommerce.

Pada kegiatan perngabdian ini untuk tim pengabdian melihat beberapa hasil dan target capaian yang sesuai dengan tujuan dari kegiatan pembinaan kepada masyarakat ini adalah:

1. Motivasi. Peserta dalam pengabdian ini terutama masyarakat yang sangat antusias untuk mengetahui pengaruh baik yang dapat ditimbulkan akibat mengetahui caranya meningkatkan pendapatan ibu-ibu rumah tangga untuk membantu perekonomian keluarga.

2. Fasilitas-fasilitas yang akan disediakan oleh Pengusul UPB sesuai dengan kebutuhan pembinaan

Berdasarkan praktek langsung cara membuat es krim bersama ibu-ibu yang telah dilakukan di perumahan Citra Laguna, Batu Aji - Batam, diharapkan dapat memberikan dampak yang positif kepada para peserta dan juga kepada tim dosen yang melakukan pembinaan (PKM), secara lebih rinci hasil yang dicapai dari pelaksanaan pembinaan tersebut dapat diuraikan antara lain sebagai berikut:

1. Terjalinnya kerjasama antara Universistas Putera Batam dengan Kelurga Perumahan Citra Laguna, Batu Aji - Batam. 
2. Peserta (ibu-ibu) diberikan pengetahuan dan pembinaan dengan praktek langsung mengenai cara membuat es krim.

3. Peserta (ibu-ibu) diberikan pengetahuan dan pembinaan dengan praktek langsung mengenai cara memasarkan produk es krim secara e-commerce. Dimulai dengan pengenalan e-commerce, mengunduh gambar produk hingga merangkai Bahasa pemasaran untuk promosi.

4. Peserta diberikan pembinaan dengan metode memgajarkan dan membagi informasi tentang cara memasarkan mulai dari langkah menjual, promosi, hingga menjaga dan mempertahankan pelanggan.

5. Menambah pengetahuan ibu-ibu di Perumahan Citra Laguna, Batu Aji, Batam.

6. Mengembangkan dan berbagi ilmu pengetahuan kepada masyarakat yang ada, khususnya Perumahan Citra Laguna, Batu Aji - Batam.

Sebelum pemateri memberikan praktek langsung membuat es krim, terlebih dahulu pemateri melakukan diskusi dengan aparat setempat dilanjutkan dengan para ibu-ibu di Perumahan Citra Laguna, Batu Aji - Batam, selanjutnya pemateri membahas rencana dan menyesuaikan dengan kebutuhan akan pengetahuan ibu-ibu di Perumahan Citra Laguna, Batu Aji - Batam. Kesepakatan Antara ibu-ibu dengan tim dosen PKM adalah selama memberikan pembinaan dan praktek langsung, tim dosen memulai dengan memberikan materi tentang cara menjalankan e-commerce. Selanjutnya langsung membimbing ibu-ibu peserta mempraktekkan langsung. Demikian halnya dengan materi-materi lainnya.

Materi pembinaan dari hari pertama sampai dengan hari kedua yang disampaikan sewaktu pengabdian kepada ibu-ibu di Perumahan Citra Laguna, Batu Aji - Batam, berupa: Hari Pertama (Sabtu, 17 Agustus 2019), praktek cara membuat es krim. Hari Kedua (18 Agustus 2019), dilanjutkan dengan praktek cara pemasaran secara e-commerce.

Secara garis besar, kegiatan PKM yang berlangsung dua kali pertemuan ini menjawab dan memberikan solusi untuk permasalahan berikut: (1) Bagaimanakah upaya membina masyarakat (ibu-ibu rumah tangga) untuk meningkatkan perekonomiannya agar dapat membantu keluarga? (2) Bagaimanakah perjanjian jual beli es krim yang penjualannya dilakukan secara e-commerce?

Solusi dari pembinaan ini memberikan masyarakat adalah:

1. Pembinaan yang dilakukan meningkatkan pemahaman, pengetahuan, kepada masyarakat bahwasannya e-commerce dapat dijadikan upaya untuk mencari pendapatan tambahan.

2. Pembinaan diberikan terhadap masyarakat untuk menjauhkan masyarakat mendapatkan barang yang berkualitas namun harganya murah dan terjangkau.

3. Memberikan pemahaman tentang jenis-jenis es-krim yang dapat dihasilkan dari pembinaan ini.

4. Memberikan akibat yang akan ditimbulkan jika pengabdian ini dilaksanakan oleh Tim pengabdi.

5. Memberikan pengetahuan yang dapat dijadikan sumber pendapatan.

6. Memberikan pengetahuan mengenai hukum dan ekonomi apabila hasil pengabdian ini dijual atau sudah mendapat pasar sendiri. 


\section{KESIMPULAN}

Berdasarkan pembahasan pembinaan yang diberikan pada ibu-ibu di Perumahan Citra Laguna, Tembesi-Batam Batu Aji - Batam di atas, maka disimpulkan sebagai berikut:

1. Peserta memahami dan bisa mempraktekkan langsung cara membuat es krim hingga setelah pembinaan memalui praktek yang diberikan oleh Tim Pengabdi.

2. Peserta memahami dan bisa mempraktekkan langsung cara mengerjakan pemasaran melalui e-commerce, mulai dari membuat akun, mengunduh gambar produk dan membuat bahasa pemasaran.

3. Peserta memahami tentang penyajian jual beli secara online.

\section{DAFTAR PUSTAKA}

Helmalia, \& Afrinawati. (2018). Pengaruh e-commerce terhadap peningkatan pendapatan usaha mikro kecil dan menengah di kota padang helmalia. JEBI (Jurnal Ekonomi Dan Bisnis Islam), 3(2), 238-246.

Istiqomah, K., Windrati, W. S., \& Praptiningsih, Y. (2017). Karakterisasi Es Krim Edamame dengan Variasi Jenis dan..... Jurnal Agroteknologi Vol. 11 No. 02 (2017). 11(02), 139-147.

Kasmi, K., \& Candra, A. N. (2017). Penerapan E-Commerce Berbasis Business To Consumers Untuk Meningkatan Penjualan Produk Makanan Ringan Khas Pringsewu. Jurnal AKTUAL, 15(2), 109. https://doi.org/10.47232/aktual.v15i2.27

Maryama, S. (2019). Penerapan E-Commerce Dalam Meningkatkan Daya Saing Usaha. Liquidity, 2(1), 73-79. https://doi.org/10.32546/lq.v2i1.132

Nainggolan, N. P., \& Utnasari, I. (2021). Pembinaan Membuat Aplikasi Toko Online Sebagai Media Promosi Pada Home Industry Masyarakat Tanjung Gundap RT.02/ RW.01. PUAN INDONESIA, 2(2), 135-146. https://doi.org/10.37296/jpi.v2i2.40

Parahyangan, U. K., Ekonomi, F., Studi, P., \& Ekonomi, S. (2013). Pengaruh ECommerce Terhadap Pertumbuhan Ekonomi Indonesia. Pengaruh ECommerce Terhadap Pertumbuhan Ekonomi Indonesia, 211.

Pradana, M. (2015). Klasifikasi Jenis-Jenis Bisnis E-Commerce. Klasifikasi JenisJenis Bisnis E-Commerce Di Indonesia, 9(2), 32-40.

Yulistia, Y. (2017). Analisis Pengaruh Efektivitas Dan Manfaat E-Commerce Terhadap Sikap Dan Perilaku Pengguna Dengan Menggunakan Metode TAM (Studi Kasus: UKM Kota Palembang). JATISI (Jurnal Teknik Informatika Dan Sistem Informasi), 4(1), 93-100. https://doi.org/10.35957/jatisi.v4i1.91 